\title{
Content Analysis of Master Theses and Dissertations Based on Action Research
}

\author{
Gürhan Durak ${ }^{1}$, Eyup Yünkül ${ }^{1}$, Serkan Cankaya ${ }^{1}$, Şükran Akpınar $^{1}$, Emine Erten ${ }^{1}$, Nazmiye Inam ${ }^{1}$, Ufuk Taylan ${ }^{1}$, \\ Mehmet Urfa ${ }^{1}$ \\ ${ }^{1}$ Computer Education and Instructional Technologies, Balıkesir University, Turkey \\ Correspondence: Gürhan Durak, Computer Education and Instructional Technologies, Balıkesir University, Turkey.
}

Received: October 5, 2016

Accepted: October 26, 2016

Online Published: November 3, 2016

doi:10.11114/jets.v4i12.1906

URL: http://dx.doi.org/10.11114/jets.v4i12.1906

\begin{abstract}
Action Research (AR) is becoming popular in the field of education, and according to literature, it could be stated that AR studies have positive influence on practice in education. The present study aims at conducting content analysis of action research (AR) master theses and doctoral dissertations submitted at the level of Turkish higher education. A total of 10 master theses and 18 doctoral dissertations were analyzed to determine their action research type, keywords, theoretical framework, academic discipline, test and analysis, data collection tools, participants, variables and research interest and leader institutions. Furthermore, the action research purposes of these theses and dissertations were analyzed with qualitative methods. In this respect, the present study is thought to be significant in that by reviewing the action research theses/dissertations, it helps clarify the current status of the action research field in Turkey and determine the research trends in this area. As a result, more than half $(57 \%)$ of theses/dissertations were determined to fall into the "Technical/scientific/collaborative" type. Besides, in relation to theoretical frameworks, "constructivism" was found to be dominant in the theses/dissertations analyzed. Interview and participant observation notes were the most popular data collection tools. Lastly, according to their statements of purpose, the theses/dissertations could be gathered under 3 themes: "development", "actualization", and "application".
\end{abstract}

Keywords: action research, research trends, master's thesis, doctoral dissertation, content analysis

\section{Introduction}

Action research, grounded in the fundamental work by Kurt Lewin, is a systematic research process that aims at bringing effective solutions to the problems encountered in everyday life (Ferrance, 2000; Stringer, 2007). From an educational perspective, action research can be defined as the process of joint exploration carried out by shareholders to comprehend and raise the quality of instructional actions (Hensen, 1996; McTaggart, 1997; Mills, 2013; Schmuck, 1997). Those involved in action research could provide changes necessary for social improvement via recurring cycles of planning, observing, and reflecting (Hine, 2013).

Based on these definitions, action research can be described as the type of systematic and in-depth research process carried out by an individual or by a group (Beverly, 1993) to determine the problems experienced in the application processes or to solve existing problems (Beyhan, 2013) as well as to improve such processes (Sagor, 2004; Riel, 2016). When the relevant literature is reviewed, it is seen that there are various labels for action research. According to O'Brien (2001), some of these labels include participatory research, collaborative inquiry, emancipatory research, action learning or contextual action research. Underlying all these labels is "learning by doing", which implies that when a group of people face a problem, they do something to solve that problem and check how effective their solution is. If the problem is still unsolved, they try another solution (Atmaca, 2016). The loop continues until the problem is solved.

\subsection{Types of Action Research}

In related literature, there are a number of classifications regarding types of Action Research (AR) in terms of researchers, practitioners, and their roles. Generally, it could be stated that the most common one is the three-type classification (Berg, 2001; Grundy, 1982; Holter \& Schwartz-Barcott, 1993; Kemmis \& McTaggert, 2007; McKernan, 1991). These are (1) technical/scientific/collaborative, (2) practical/mutual collaborative/deliberative and (3) emancipating/enhancing/critical science. Technical/scientific/collaborative is a positivist AR type, in which the researcher directs the application within a certain theoretical framework to make the application more effective on the 
basis of the data gathered via the application (Newton \& Burgess, 2008; Yildirim \& Simsek, 2011, Ozpinar \& Aydogan Yenmez, 2013). Practical/mutual collaborative/deliberative AR is much more flexible than the "technical/scientific/collaborative" type and is more practice-oriented since it focuses on the problems involved in the application and on the causes of these problems (Norton, 2009). Another type, emancipating/enhancing/critical science $\mathrm{AR}$, aims at allowing practitioners to develop a critical viewpoint about their own studies and to acquire new experiences and knowledge. Moreover, the further purpose is to help practitioners perceive the process as a problem-solving process and to help them bring reasonable solutions to problems. In this way, the practitioners will have a powerful and free role (Newton \& Burgess, 2008; Yildirim \& Simsek, 2011, Ozpinar \& Aydogan Yenmez 2013). AR studies included in the present study were evaluated according to this type of classification.

\subsection{Significance and Purpose of the Study}

While AR usually falls into the qualitative research category, it is also used in quantitative research and more recently has come into prominence as an approach used by academicians and teachers to obtain information and to improve practice. The most important goals of AR in the field of education include understanding the problems in the process of education and trying to produce solutions to these problems by introducing the necessary changes. According to Uzuner (2005), with their increasing popularity particularly in the field of education, AR studies have positive influence on teachers' professional development. Teachers' active involvement in the research process allows them to view and improve their own work from a more critical perspective. Therefore, due to the increasing popularity of constructivist education and related new curricula, educational research is moving towards action research (Artvinli, 2010).

As part of this study, the keyword of "Action Research" was searched in the database of Web of Science in the category of articles (as of April 3, 2016), and the annual distribution of a total of 3458 articles can be seen in Figure 1.

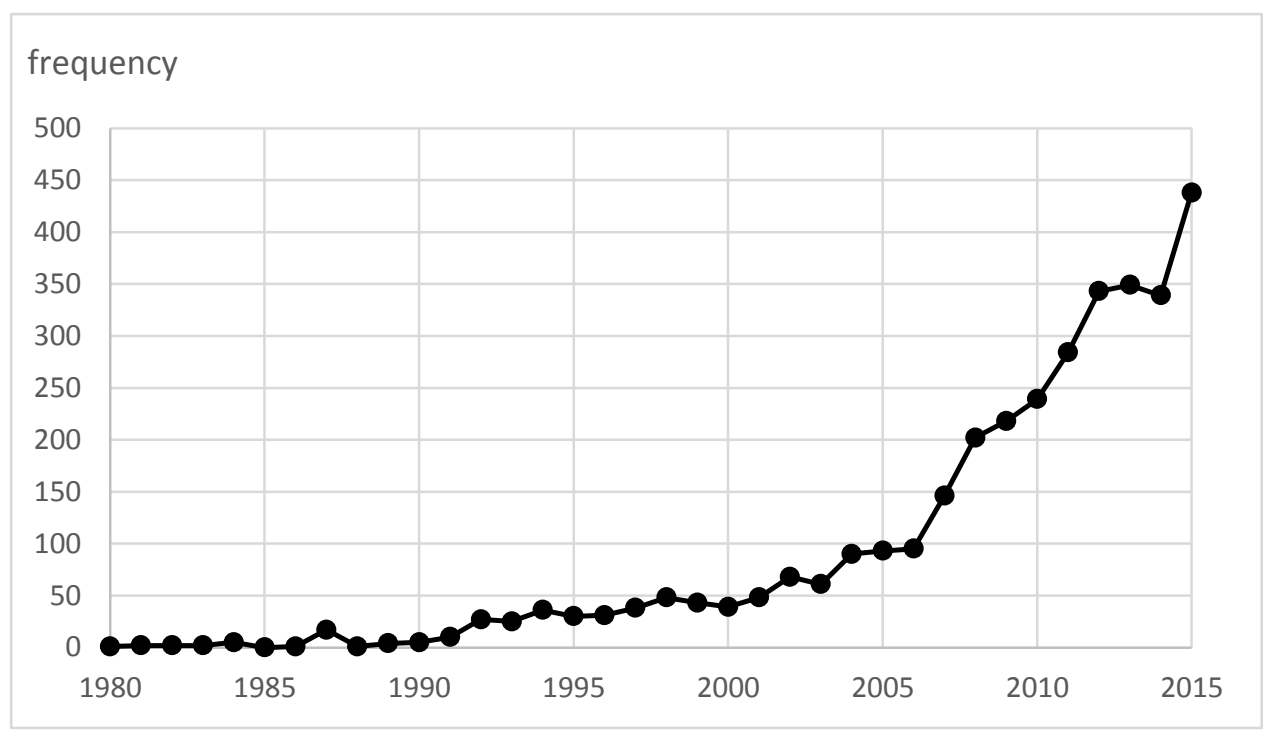

Figure 1. Annual distribution of 3458 articles

According to Figure 1, although there is no remarkable change in the number of articles until 2000s, starting from that year on, a considerable rise is observed. From 2007 on, the number of studies goes up, and the highest number of studies conducted is in 2015. Thus, considering such a rise in the frequency of use of the keyword of action research in studies over the years, it could be concluded that the importance of this subject has gradually increased. However, our comprehensive review of the AR literature revealed that there is no content analysis conducted to examine AR studies. The present study aims at analyzing AR master theses and doctoral dissertations in Turkey in terms of "keywords, theoretical background, academic discipline, test and analysis, data collection tools, participants, university and variables/research interest". Additionally, themes were formed by analyzing the problem statements of the related theses/dissertations with qualitative analysis methods.

In sum, the present study aims at providing answers to the following research questions:

1. What are the most frequently used action research types in action research studies?

2. What are the most frequently used keywords in action research studies?

3. What are the trends in theoretical backgrounds in action research studies?

4. What academic disciplines are the action research studies from? 
5. What are the most frequently used data collection instruments and data analysis techniques in action research studies?

6. What are the most frequently targeted participant groups in action research studies?

7. What are the most frequently focused variables in action research studies?

8. What are the themes related to the statements of purpose in action research studies?

9. What are the leading institutions where action research studies are conducted?

\section{Method}

In the present study, content analysis was run on the theses/dissertations conducted in the field of action research in Turkey. The theses/dissertations were accessed via the database of Turkish Council of Higher Education (TCHE). TCHE has an electronic database which includes all the M.A. theses and doctoral dissertations submitted so far in Turkey, which are all accessible for researchers.

While reviewing the literature, the following criteria were taken into account for the theses/dissertations:

The theses/dissertations should be

1. included in the database of TCHE,

2. conducted in action research type,

3. a dissertation or a master's thesis,

4. accessible to all researchers.

The 'search' was done by typing "action research" as the keyword to determine the related theses/dissertations. As a result of this search, a total of 31 theses/dissertations (13 master's theses and 18 doctoral dissertations) were accessed by April 29, 2016. However, after excluding 4 irrelevant theses/dissertations, a total of 28 theses/dissertations were finally included in the present study.

In order to find answers to the research questions, content analysis was conducted, and the related theses/dissertations were examined with respect to certain variables. The descriptive statistics regarding the variables in the dissertations were examined with percentages and frequencies. Furthermore, in order to determine the subjects of the action research studies, the statements of purpose of the theses/dissertations were analyzed with qualitative methods.

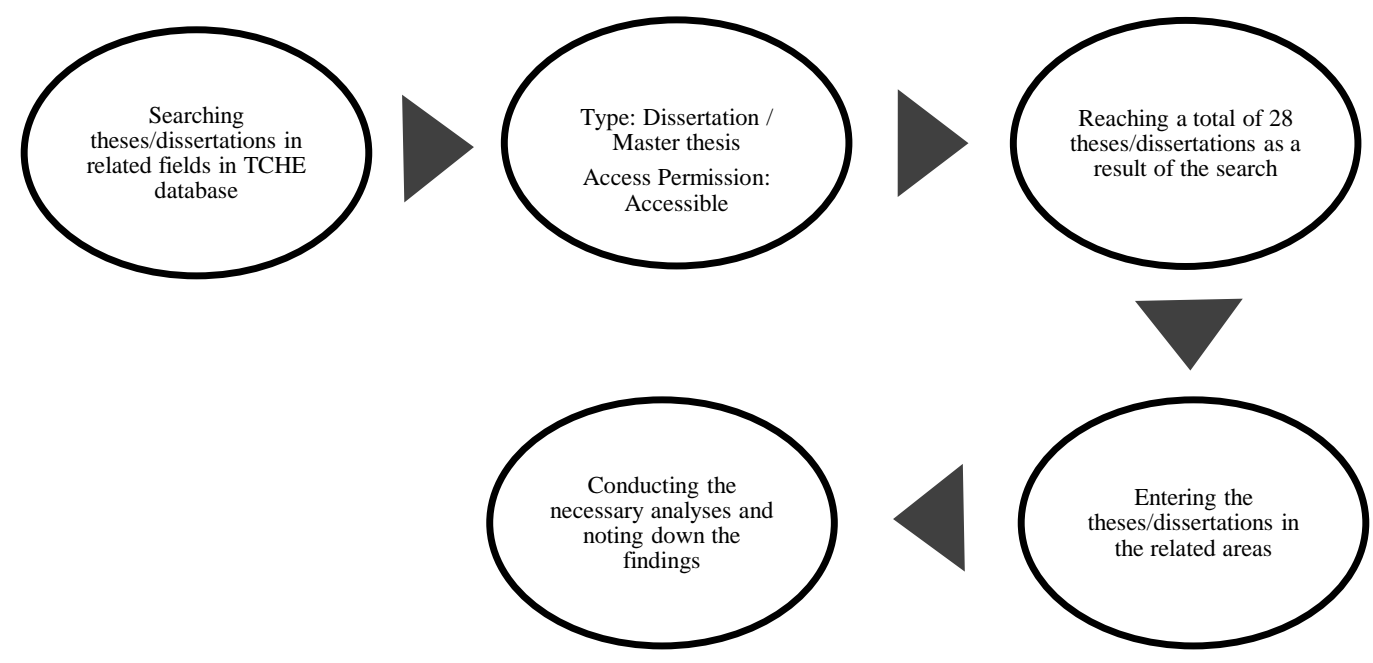

Figure 2. Diagram of thesis/dissertation search process

\subsection{Reliability}

A table was prepared for the theses/dissertations reached via the search on the basis of the previously defined criteria, and three researchers analyzed the dissertations individually and noted the results down in their own tables. Following this, the tables prepared by the researchers were compared. As a result, the differences were identified, and the related theses/dissertations were examined again. Inter-rater reliability of the second-round coding was $\kappa=.875$. Altman (1990) proposes that the extent of agreement for Cohen's kappa can be qualified as poor $(<0.20)$, fair $(0.21$ to 0.40$)$, moderate ( 0.41 to 0.60$)$, good ( 0.61 to 0.80$)$, and very good ( 0.81 to 1.00$)$. Thus, the reliability of first and second raters can be considered as very good. The content analysis was finalized when consensus was reached on all the findings. 


\section{Findings and Discussion}

In this part of the study, the results obtained are presented and interpreted by comparing them with those of other studies in related literature.

\subsection{Action Research Types}

The analysis of the theses/dissertations did not yield any information about whether they belong to any action research type. Therefore, the classification in the literature was taken into account, and the type of thesis/dissertation was determined through consensus by the researchers. Table 1 presents the data regarding the types of the theses/dissertations.

Table 1. Action Research Types

\begin{tabular}{lcc}
\hline Action Research Type & $\mathbf{f}$ & $\mathbf{\%}$ \\
\hline Technical/scientific/collaborative & 16 & 57 \\
Practical/mutual collaborative/deliberative & 10 & 36 \\
Emancipating/enhancing/critical science & 2 & 7 \\
Total & 28 & 100
\end{tabular}

According to Table 1, the highest number of action research master's theses and doctoral dissertations in Turkey belongs to the "Technical/ scientific/ collaborative" type $(\mathrm{f}=16)$, which is followed by "Practical/ mutual collaborative/ deliberative".

\subsection{Keywords}

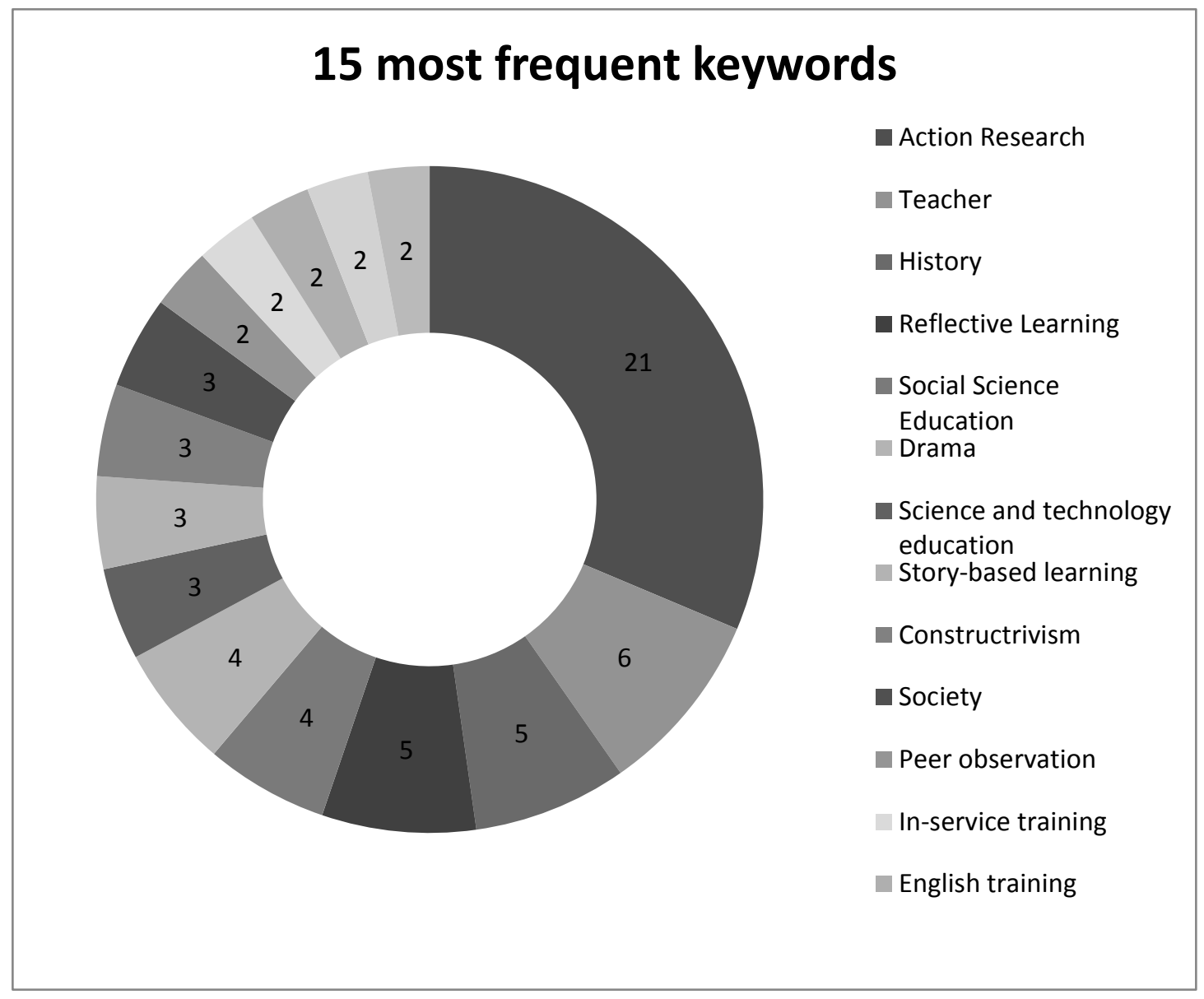

Figure 3. Keywords

The keywords used for the theses/dissertations included in the present study are given in Figure 3. The keywords considered to be irrelevant to action research were excluded from the study, and it was seen that the remaining 60 different keywords were used 114 times in total. The most frequent keyword was "Action Research" (N=21). The 
keyword of "Teacher" ( $\mathrm{N}=6)$ was the second most frequent, which might be due to the occasional use of "teacher research" instead of "action research" in the related literature. The other keywords in Figure 3 could be said to have a more balanced distribution. Though not mentioned in Figure 3 the least frequent keywords in the theses/dissertations were "Writing Education" ( $\mathrm{N}=1)$ and "Reflection Diaries" $(\mathrm{N}=1)$.

\subsection{Theoretical/Conceptual Framework}

The theses/dissertations were also analyzed from the perspective of theoretical frameworks, and the frameworks agreed upon by the researchers are presented in Table 2.

Table 2. Popular theoretical frameworks

\begin{tabular}{lcc}
\hline Theory / Framework & Frequency & Percentage \\
\hline Constructivism & 11 & 39 \\
Critical Approaches & 4 & 14 \\
Reflective thinking & 2 & 7 \\
Action Research Approach & 2 & 7 \\
Multiple Intelligences Theory & 2 & 7 \\
Life-long learning & 2 & 7 \\
Other & 5 & 18 \\
Total & 28 & 100 \\
\hline
\end{tabular}

Table 2 demonstrates that the theses/dissertations fell into seven different categories together with the category of "other" (Socio-cultural theory...) with respect to their theoretical frameworks. According to Table 2, the most common framework was "Constructivism" (39\%). Another commonly popular framework was Critical Approaches (14\%). The distributional percentages of the other theoretical frameworks appeared to be equal.

\subsection{Academic Disciplines}

The theses/dissertations were also analyzed in terms of their academic disciplines, and the results are given in Table 3 below.

Table 3. Distribution of Theses/Dissertations in terms of Academic Disciplines

\begin{tabular}{lcc}
\hline Academic Disciplines & Frequency & Percentage \\
\hline Primary School Teaching & 5 & 17,9 \\
Foreign Language Education & 5 & 17,9 \\
Primary School Science Teaching & 4 & 14,3 \\
Middle School STEM Education (OFMA) & 3 & 10,7 \\
Primary School Social Sciences Teaching & 3 & 10,7 \\
Educational Sciences & 2 & 7,1 \\
Public Health Program & 2 & 7,1 \\
Computer and Instructional Technologies Education & 1 & 3,6 \\
Industrial Design & 1 & 3,6 \\
Special Education & 1 & 3,6 \\
Art Teaching & 1 & 3,6 \\
Total & 28 & 100 \\
\hline
\end{tabular}

In terms of the academic disciplines involved in the action research studies, "Primary School Teaching" (18\%) and "Foreign Language Education" (18\%) programs rank the first and second in the list. These two programs were followed by "Primary School Science Teaching" (14,3\%) and "Social Sciences Teaching" (10,7\%).

\subsection{Tests and Analyses}

Table 4 presents the analysis techniques (as numbers and percentages) in the dissertations. 
Table 4. Distribution of Theses/Dissertations with respect to Tests and Analyses

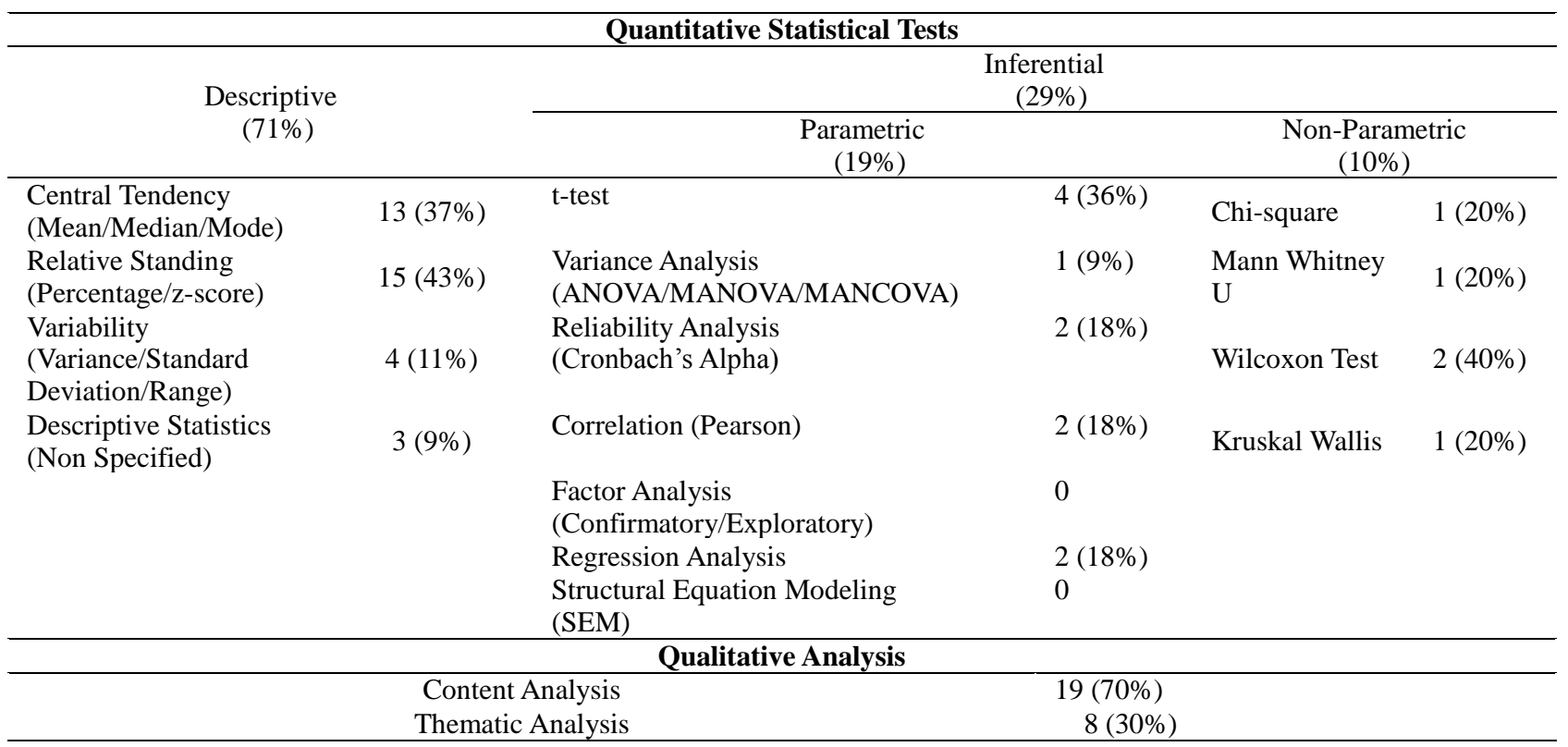

*One study may employ more than one statistical test

Table 4 presents the number and percentages of the analysis techniques used in the dissertations. Accordingly, in $71 \%$ of the quantitative statistical tests, the method of "descriptive statistics" was used, and in $29 \%$ of them, the method of "inferential statistics" was used. As for the qualitative analyses, "content analysis" was used in $70 \%$ of them, and in the remaining 30\%, the "thematic analysis" technique was used.

A closer look at Table 4 reveals that the majority of the descriptive statistics included percentage and $\mathrm{z}$-score values (43\%), followed by such central tendency statistics (37\%) as mean/median and mode and by such variability statistics $(11 \%)$ as variance/standard deviation and range. Most of the inferential statistics include parametric tests. The most common parametric test is t-test. T-test is a widely applied test for many review studies (Bozkurt et al., 2015; Davies, Howell \& Petrie, 2010). Regarding non-parametric tests, Wilcoxon test turns out to be used more frequently.

\subsection{Data Collection Tools}

Table 5 presents the frequencies and percentages regarding the data collection tools used in the theses/dissertations.

Table 5. Data Collection Tools

\begin{tabular}{lcc}
\hline Data Collection Tools & Frequency & Percentage \\
\hline Interview & 22 & 22 \\
Participant observation notes & 17 & 17 \\
Documents & 16 & 16 \\
Questionnaire & 12 & 12 \\
Observation & 12 & 12 \\
Pre-test/Post-test & 9 & 9 \\
Scale & 7 & 7 \\
Focus group & 2 & 2 \\
Electronic documents-Log & 2 & 2 \\
Others (rubric, portfolio) & 1 & 1 \\
TOTAL & 100 & 100 \\
\hline
\end{tabular}

*One study may employ more than one data collection tools

Analysis of Table 5 shows that the majority of the action research type studies employed "interview" as their data collection tool, which was followed by "Participant observation notes" and "documents". Taken together, the top five data collection tools could be said to constitute $79 \%$ of all the data collection tools used in the studies. In the studies involving the use of multiple data collection tools, the focus group, electronic documents-log, rubric and portfolio tools were used once or twice. 


\subsection{Participants}

Table 6 presents the frequencies and percentages regarding the participants in the theses/dissertations.

Table 6. Participants

\begin{tabular}{lccc}
\hline Participants & Frequency & Percentage & Sample size \\
\hline K12-Students & 15 & 53,5 & $6-52$ \\
Undergraduate Students & 4 & 14,4 & $11-30$ \\
K12-Teachers & 3 & 10,8 & $5-150$ \\
Academicians & 3 & 10,8 & $3-6$ \\
Other & 3 & 10,5 & $8-440$ \\
TOTAL & 28 & 100 & $3-440$ \\
\hline
\end{tabular}

According to Table 6, the most popular participant group was "K-12 students". This group constituted more than $50 \%$ of the participant groups. This group was followed by "undergraduate students" (14\%). When all these participant groups were analyzed with respect to their "sample size", this value was 6-52 for the group of "K12 students", while it was 11-30 for the group of "undergraduate students".

\subsection{Variables/Research Interests}

The theses/dissertations were categorized with respect to the dependent variables. Table 7 presents the related frequencies and percentages of variables/research interests.

Table 7. Variables/Research Interests

\begin{tabular}{lcc}
\hline Dependent Variable & Frequency & Percentage \\
\hline Skill & 7 & 18,42 \\
Success & 5 & 13.16 \\
Attitude & 4 & 10,53 \\
Performance & 4 & 10,53 \\
Perception & 3 & 7,89 \\
Motivation & 3 & 7,89 \\
Interest & 2 & 5,26 \\
Other & 10 & 26,32 \\
TOTAL & 38 & 100 \\
\hline
\end{tabular}

According to Table 7, when the studies were analyzed with respect to their variables/research interest, the most frequent variable was found to be the variable of "skill" (18\%), which was followed by "success" (13\%) and "attitude" (11\%). In a total of 28 theses/dissertations, 38 different variables were used.

\subsection{Analysis of the Statements of Purpose in the Studies}

The statements of purpose in the studies were determined by the researchers and subjected to content analysis. The themes obtained by consensus are given in Table 8 . 
Table 8. Themes

\begin{tabular}{lc}
\hline Themes & Frequency \\
\hline Development & 6 \\
Personal & 5 \\
Skill & 1 \\
Professional & 1 \\
Leadership & 1 \\
Literacy & 1 \\
Performance & 3 \\
Activity & 2 \\
Interaction & 1 \\
Implicit learning & 1 \\
Authentic stories & \\
Teaching method & 7 \\
Teaching concept & 4 \\
Teaching analysis & 4 \\
\hline
\end{tabular}

According to Table 8 , the themes were grouped under 4 headings. In the purpose section of the studies, the most recurrent theme was the "teaching method application" under the theme of "application", which was followed by "personal" and "skill" development in the "development" category and by "teaching concept" and "teaching analysis" in the "application" category.

\subsection{Leader Institutions}

Table 9 presents the year-based distribution of the institutions where the dissertations were produced.

Table 9. Leader Institutions

\begin{tabular}{|c|c|c|c|c|c|c|c|c|c|c|c|}
\hline Universities & ฮิ & 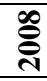 & 을 & 을 & $\overline{\bar{\nu}}$ & 곡 & $\stackrel{m}{\stackrel{\sim}{*}}$ & 龒 & $\frac{10}{8}$ & हैं & $\%$ \\
\hline Gazi University & & 1 & & 1 & & 2 & & 1 & & 5 & 17,9 \\
\hline Anadolu University & & 3 & & & & 1 & & & & 4 & 14,3 \\
\hline Karadeniz Technical University & 1 & & & & & 1 & & & & 2 & 7,1 \\
\hline Marmara University & & & & & 1 & & & & 1 & 2 & 7,1 \\
\hline Hacettepe University & & & & & 1 & & 1 & & & 2 & 7,1 \\
\hline Ataturk University & & & 1 & & & & & 1 & & 2 & 7,1 \\
\hline Middle East Technical University & & & & & & 1 & & & & 1 & 3,6 \\
\hline Ege University & & & 1 & & & & & & & 1 & 3,6 \\
\hline Mehmet Akif Ersoy University & & & & 1 & & & & & & 1 & 3,6 \\
\hline Selcuk University & & & & & 1 & & & & & 1 & 3,6 \\
\hline Bilkent University & & & & & 1 & & & & & 1 & 3,6 \\
\hline Rize University & & & & & & 1 & & & & 1 & 3,6 \\
\hline Istanbul Technical University & & & & & 1 & & & & & 1 & 3,6 \\
\hline Recep Tayyip Erdogan University & & & & & & & 1 & & & 1 & 3,6 \\
\hline Adiyaman University & & & & & & & & 1 & & 1 & 3,6 \\
\hline Cag University & & & & & & & & 1 & & 1 & 3,6 \\
\hline Cukurova University & & & & & & & 1 & & & 1 & 3,6 \\
\hline Total & 1 & 4 & 2 & 2 & 5 & 6 & 3 & 4 & 1 & 28 & 100 \\
\hline
\end{tabular}

Analysis of Table 9 indicates that among the leading institutions where the AR studies conducted in Turkey was Gazi University (18\%), which was followed by Anadolu University with a percentage of 14,3\%. Year-by-year analysis revealed that until 2008, there was only one action research study. After 2008, action research studies gained momentum, and the highest number of studies was in $2012(n=6)$. One reason for the low number of studies in the last three years could be given as the 3-year access block put on the theses/dissertations in the TCHE database.

\subsection{Limitations and Strengths}

Within the scope of this study, the database of TCHE (Theses Center for Higher Education) was searched, and a total of 31 accessible theses/dissertations were reached. In addition, three irrelevant theses/dissertations were excluded from the study. Therefore, the fact that the theses/dissertations with no access permission were not included in the study and that there was only one thesis/dissertation conducted in 2016 could be regarded as the limitation for the present study.

This study is thought to be significant because by carrying out the first content analysis of the theses/dissertations in the field of action research, it lays out the current status of the scholarship in the field of AR in Turkey. The findings obtained in the present study are expected to contribute to future studies by providing insights into this specific field. 


\section{Conclusion, Discussion and Suggestions}

In this study, content analysis was conducted for the doctoral dissertations and master's theses carried out as action research in Turkey. The relevant theses/dissertations were analyzed under the following headings: action research type, keywords, theoretical framework, academic discipline, test and analysis, data collection tools, participants, variables and research interest and leader institutions. Apart from that, statements of purpose in the theses/dissertations were subjected to qualitative analysis, and themes were created by coding. The action research theses/dissertations fall into three categories according to a classification widely used in related literature. By consensus of the researchers, more than half $(57 \%)$ of the theses/dissertations were found to fall into the "Technical/scientific/collaborative" type. When the theses/dissertations were analyzed with respect to keywords, it was found that the keyword of "action research" was used with the highest frequency, which was an expected result for the action research theses/dissertations included in the present study. The keyword of "action research" was followed by the keyword of "teacher", which could be explained by the fact that "action research" is sometimes referred to as "teacher research" in literature. Concerning theoretical frameworks, "constructivism" was found to be dominant in the theses/dissertations analyzed. When they are ranked with respect to the academic discipline they belong to, the theses/dissertations demonstrated a balanced distribution. Accordingly, Primary School Teaching, Foreign Language Education, and Science Teaching rank high on the list. The test and analysis dimension of the theses/dissertations reveals that "descriptive" studies are dominant (71\%). Among the descriptive statistics, the most common ones include "percentage /z-score" and mean/median/mode values, while for "inferential" statistics, t-test is the most frequent. In terms of the qualitative analysis methods, $70 \%$ of them used content analysis. Interview and participant observation notes were the most popular data collection tools, which could be said to be in line with the nature of action research. As for the participant groups, the theses/dissertations focused on K-12 students most. In terms of sample sizes, 3 to 440 participants were included in the theses/dissertations. As for variables/research interest, "skill" and "success" are the most frequent ones. Most of the 28 theses/dissertations analyzed were conducted at Gazi University (18\%). Lastly, statements of purpose in the theses/dissertations were examined by conducting qualitative analyses. As a result, the codes were formed, and the related themes were determined. According to their purpose statements, the theses/dissertations could be gathered under three themes: "development", "actualization", and "application". In relation to these themes, it could be stated that studies were conducted on "personal development" and on "the application of an instructional method".

As review of the related literature demonstrated that there is no study conducted to examine action research studies, the present study is expected to be a pioneering one. In the light of the findings obtained in the study, the following suggestions could be put forward:

- Researchers who plan to conduct action research may benefit from the findings of the present study and make use of the dimensions examined in the present study.

- Conducting this study in an international scale and using multiple databases like "Web of Science" may yield further significant results by providing research sample diversity.

- With content analyses conducted on extensive sampling, various variables (country, language, article, thesis, etc.) could be compared.

\section{References}

Altman, D. G. (1990). Practical statistics for medical research. London: CRC press.

Artvinli, E. (2010). Cografya derslerini yapilandirmak: aksiyon (eylem) arastirmasina dayali bir ders tasarimi. Marmara Cografya Dergisi, 21, 184-218.

Atmaca, Ç. (2016). Comparison of hedges in M.A..Theses and Ph.D. Dissertations in ELT. Journal of World of Turks, $8(2), 309-325$.

Berg, B. L. (2001). Qualitative research methods for the social sciences (4th ed.). Boston: Allyn and Bacon.

Beyhan, A. (2013). Egitim orgutlerinde eylem arastirmasi. Bilgisayar ve Egitim Arastirmalari Dergisi, 1(2), 65-89.

Bozkurt, A., Kumtepe, E. G., Kumtepe, A. T., Aydin, I. E., Bozkaya, M., \& Aydin, C. H. (2015). Research trends in Turkish distance education: A content analysis of dissertations, 1986-2014. European Journal of Open, Distance and E-learning, 18(2). http://dx.doi.org/10.1515/eurodl-2015-0010

Davies, R., Howell, S., \& Petrie, J. (2010). A review of trends in distance education scholarship at research universities in North America, 1998-2007. In The International Review of Research in Open and Distance Learning, 11(3), $42-56$.

Ferrance, E. (2000). Themes in education: Action research. Providence, Rhode Island: Northeast and Islands Regional Educational Laboratory At Brown University. 
Grundy, S. J. (1982). Three modes of action research. Curriculum Perspectives, 2(3), 23-34.

Henson, K. T. (1996). Teachers as researchers. In J. Sikula, T. Buttery, \& E. Guyton (Eds.), Handbook of research on teacher education (2nd ed.) (pp.53-64). New York: Simon \& Schuster

Hine, G. S. C. (2013). The importance of action research in teacher education programs. Issues in Educational Research, 23(2), 151-163.

Holter, I. M., \& Schwartz-Barcott, D. (1993). Action research: What is it? How has it been used and how can it be used in nursing? Journal of Advanced Nursing, 128, 298-304. http://dx.doi.org/10.1046/j.1365-2648.1993.18020298.x

Johnson, B. (1993). Teacher as researcher. Washington, D.C: ERIC Clearinghouse on Teacher Education.

Kemmis, S., \& McTaggart, R. (2007). Participatory action research: Communicative action and the public sphere. In N. K. Denzin, \& Y.S. Lincoln (Eds.), The sage handbook of qualitative research. Thousand Oaks, CA: Sage.

McKernan, J. (1991). Curriculum action research: A handbook of methods and resources for the reflective practitioner (2nd ed.). London: Kogan Page Limited.

McTaggart, R. (1997). Reading the collection. In R. McTaggart (Ed.), Participatory action research (pp. 1-12). Albany, NY: Suny Press.

Mills, G. E. (2013). Action research: A guide for the teacher researcher (5th Edition). Pearson.

Newton, P., \& Burgess, D. (2008). Exploring types of educational action research: Implications for research validity. International Journal of Qualitative Methods, 7(4), 18-30.

Norton, L. S. (2009). Action research in teaching and learning: a practical guide to conducting pedagogical research in universities. New York: Routledge.

O'Brien, R. (2001). An overview of the methodological approach of action research. Retrieved from http://www.web.ca/robrien/papers/arfinal.html.

Ozpinar I., \& Aydogan Yenmez, A. (2013). Kuramdan uygulamaya egitimde bilimsel arastirma yontemleri. Ankara: Pegem Yayinlari.

Riel, M. (2016). Understanding action research. center for collaborative action research, pepperdine university. Retrieved from http://cadres.pepperdine.edu/ccar/define.html.

Sagor, R. (2004). The action research guidebook: A four-step process for educators and school teams. Thousand Oaks, CA: Sage.

Schmuck, R. A. (1997). Practical action research for change. Arlington Heights, IL: Skylight Training and Publishing.

Stringer, E. T. (2007). Action research (3rd. Ed.). Sage Publication Inc.

Yildirim, A., \& Simsek, H. (2011). Sosyal bilimlerde nitel arastirma yontemleri (8th ed). Ankara: Seckin Yayincilik. 